\title{
Offspring sensitivity to ocean acidification changes seasonally in a coastal marine fish
}

\author{
Christopher S. Murray, Alex Malvezzi, Christopher J. Gobler, Hannes Baumann* \\ School of Marine \& Atmospheric Sciences, 123 Dana Hall, Stony Brook University, Stony Brook, New York 11794, USA
}

\begin{abstract}
Experimental assessments of species vulnerabilities to ocean acidification are rapidly increasing in number, yet the potential for short- and long-term adaptation to high $\mathrm{CO}_{2}$ by contemporary marine organisms remains poorly understood. We used a novel experimental approach that combined bi-weekly sampling of a wild, spawning fish population (Atlantic silverside Menidia menidia) with standardized offspring $\mathrm{CO}_{2}$ exposure experiments and parallel $\mathrm{pH}$ monitoring of a coastal ecosystem. We assessed whether offspring produced at different times of the spawning season (April to July) would be similarly susceptible to elevated $\left(\sim 1100 \mu \mathrm{atm}, \mathrm{pH}_{\mathrm{NIST}}=7.77\right)$ and high $\mathrm{CO}_{2}$ levels $(\sim 2300$ $\mu$ atm, $\left.\mathrm{pH}_{\mathrm{NIST}}=7.47\right)$. Early in the season (April), high $\mathrm{CO}_{2}$ levels significantly $(\mathrm{p}<0.05)$ reduced fish survival by $54 \%$ (2012) and $33 \%$ (2013) and reduced 1 to $10 \mathrm{~d}$ post-hatch growth by $17 \%$ relative to ambient conditions. However, offspring from parents collected later in the season became increasingly $\mathrm{CO}_{2}$-tolerant until, by mid-May, offspring survival was equally high at all $\mathrm{CO}_{2}$ levels. This interannually consistent plasticity coincided with the rapid annual $\mathrm{pH}$ decline in the species spawning habitat (mean pH: 1 April/31 May = 8.05/7.67). It suggests that parents can condition their offspring to seasonally acidifying environments, either via changes in maternal provisioning and/or epigenetic transgenerational plasticity (TGP). TGP to increasing $\mathrm{CO}_{2}$ has been shown in the laboratory but never before in a wild population. Our novel findings of direct $\mathrm{CO}_{2}$-related survival reductions in wild fish offspring and seasonally plastic responses imply that realistic assessments of species $\mathrm{CO}_{2}$-sensitivities must control for parental environments that are seasonally variable in coastal habitats.
\end{abstract}

KEY WORDS: Adaptation - Flax Pond - Growth · Larvae - Menidia menidia - Ocean acidification . Survival · Temperate tidal salt marsh · Transgenerational plasticity

Resale or republication not permitted without written consent of the publisher

\footnotetext{
*Corresponding author: hannes.baumann@stonybrook.edu
}

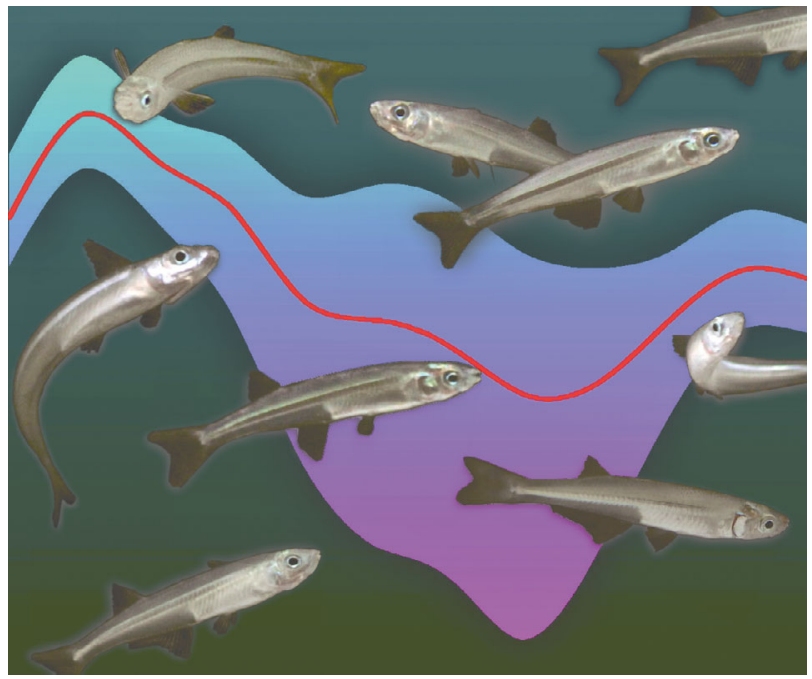

Novel experiments on wild Atlantic silversides Menidia menidia suggest that parents are capable of pre-conditioning their offspring to the naturally occurring, seasonal acidification in their spawning habitat (shape depicts the annual pattern of $\mathrm{pH}$ mean, minimum and maximum).

Artwork: H. Baumann, C. Murray

\section{INTRODUCTION}

There is growing recognition that anthropogenic ocean acidification (OA), 'mankind's other $\mathrm{CO}_{2}$ problem' (Doney et al. 2009), poses a fundamental threat to marine organisms and ecosystems (Denman et al. 2011, Branch et al. 2013). The concern is largely based on empirical data from a fast-growing body of laboratory studies that challenge contemporary organisms with $\mathrm{CO}_{2}$ levels predicted to occur in the open ocean within the next $300 \mathrm{yr}$ (up to $2000 \mu \mathrm{atm}$; Caldeira \& Wickett 2003, Riebesell et al. 2010). However, the emerging picture has remained intriguingly 
complex. While the majority of responses to high $\mathrm{CO}_{2}$ appears to be negative (Hendriks et al. 2010, Branch et al. 2013), with highest sensitivities observed during the early life stages (Kurihara 2008) and in calcifying invertebrates such as corals (Kleypas et al. 2006), bivalves (Talmage \& Gobler 2010), pteropods (Seibel et al. 2012), and echinoderms (Dupont et al. 2008), there is also substantial evidence for nonlinear (Ries et al. 2009), neutral (Munday et al. 2011, Hurst et al. 2013), or even positive reactions to increasing $\mathrm{CO}_{2}$ conditions (Gooding et al. 2009). Moreover, divergent responses and sensitivities have been observed between ecologically and taxonomically similar species (Ries et al. 2009, Hendriks et al. 2010) or even among populations within a species (Frommel et al. 2012a,b). Meanwhile, the capacity for longand short-term adaptation of marine organisms to rising $\mathrm{CO}_{2}$ levels remains largely unknown (Parker et al. 2012, Reusch 2014).

Marine fish exemplify this complexity. Decades of empirical data suggest that juvenile and adult fish possess sufficient acid-base and osmoregulatory capabilities for the toleration of very high metabolic and ambient $\mathrm{CO}_{2}$ levels (>2000 patm; Ishimatsu et al. 2008). Fish embryos and larvae, on the other hand, are still developing these physiological controls and may therefore be vulnerable to anthropogenic $\mathrm{CO}_{2}$ increases (Ishimatsu et al. 2008, Baumann et al. 2012). The recent focus on fish early life stages has yielded mixed results. For example, larvae of many coral reef species exhibited detrimental, yet reversible behavioral abnormalities when reared under elevated $\mathrm{CO}_{2}$ levels (Munday et al. 2009a, Dixson et al. 2010, Nilsson et al. 2012), whereas larvae of other species showed little or no such effects (Baumann et al. 2012, Chambers et al. 2013). Direct reductions in growth and survival in response to elevated $\mathrm{CO}_{2}$ conditions are documented for the early life stages of inland silverside Menidia beryllina (Baumann et al. 2012) and summer flounder Paralichthys dentatus (Chambers et al. 2013) but not for walleye pollock Theragra chalcogramma (Hurst et al. 2013), white sea bass Atractoscion nobilis (Checkley et al. 2009), or many coral reef fish species (Munday et al. 2009a, 2011, Dixson et al. 2010). Furthermore, while experiments on larval Atlantic cod Gadus morhua and herring Clupea harengus indicated some adverse effects of elevated $\mathrm{CO}_{2}$ (Frommel et al. 2012b), similar experiments on larval Baltic cod and herring did not (Franke \& Clemmesen 2011, Frommel et al. 2012a).

The complexity of responses among fish and other marine organisms to elevated $\mathrm{CO}_{2}$ (Ries et al. 2009) suggests the existence of highly species-specific reaction norms. Furthermore, it may indicate the existence of so far overlooked or insufficiently controlled factors in laboratory settings. One such factor is the spatio temporal $\mathrm{CO}_{2}$ and $\mathrm{pH}$ variability in marine habitats (Hendriks et al. 2010, Hofmann \& Todgham 2010, Hofmann et al. 2011, McElhany \& Busch 2012) that appears critical for 2 reasons.

First, there is increasing recognition that the majority of ecologically and economically important marine species inhabit coastal and continental shelf regions, where seasonal cycles in ecosystem metabolism (Wootton et al. 2008), river discharge (Salisbury et al. 2008), upwelling (Feely et al. 2008), or human influences (Cai et al. 2011) often lead to both more elevated and more variable $\mathrm{CO}_{2}$ conditions compared to the open ocean. As a result, contemporary coastal organisms already experience a wide range of $\mathrm{pH}$ and $\mathrm{CO}_{2}$ conditions, most of which are not predicted to occur in the open ocean for hundreds of years - if ever (Cai et al. 2011, Melzner et al. 2012).

Second, there is mounting evidence of an important but understudied link between parent and offspring generations, known as parental conditioning or transgenerational plasticity (TGP), that may comprise a short-term adaptation mechanism to environmental acidification. TGP describes the ability of the parental environment prior to fertilization to influence offspring reaction norms without requiring changes in DNA sequence (Salinas \& Munch 2012), a phenomenon often attributed to epigenetic inheritance and found in such diverse taxa as plants, insects, marine invertebrates, and vertebrates, including humans (Jablonka \& Raz 2009, Salinas et al. 2013). TGP in temperature-dependent growth was recently documented for 2 fish species, where offspring performed better at higher temperatures if the parents had experienced these temperatures as well (Donelson et al. 2012, Salinas \& Munch 2012). TGP in $\mathrm{CO}_{2}$ resistance as a potential adaptation for coping with highly variable aquatic $\mathrm{CO}_{2}$ environments may be equally common (Salinas \& Munch 2012, Dupont et al. 2013). In laboratory experiments, offspring of Sydney rock oysters Saccostrea glomerata were shown to suffer from reduced survival, growth, and calcification rates in response to elevated $\mathrm{CO}_{2}$, but the effects disappeared when the parents experienced these environments (Parker et al. 2012). Similarly, larvae of the cinnamon clownfish Amphiprion melanopus showed reductions in survival, growth, and metabolic scope when exposed to elevated $\mathrm{CO}_{2}$ levels, but again, these effects vanished by simply rearing parents at similar $\mathrm{CO}_{2}$ levels prior to fertiliza- 
tion (Miller et al. 2012). While clearly a possibility in the laboratory, it has yet to be demonstrated whether such parent-offspring linkages occur in the wild.

Here, we present multi-year, time-series $\mathrm{CO}_{2}$ exposure experiments on early life stages of the Atlantic silverside Menidia menidia, a keystone forage fish species that is widely distributed along the North American Atlantic coast. In Long Island waters $\left(\sim 41^{\circ} \mathrm{N}\right)$, the species spawns with semi-lunar periodicity from April to July in the intertidal zone of estuaries and salt marshes (Middaugh et al. 1987), i.e. coastal environments that are extremely productive and therefore likely to exhibit substantial diel to seasonal fluctuations in $\mathrm{CO}_{2}$ and $\mathrm{pH}$ conditions (Wang \& Cai 2004). We quantified these seasonal patterns of $\mathrm{pH}$ variability in the spawning habitat of $M$. menidia by analyzing long-term (2008 to 2012), high-frequency $\mathrm{pH}$ monitoring data from the Flax Pond tidal salt marsh (Long Island, NY). In parallel, we conducted a series of fully replicated and standardized experiments $\left(\mathrm{N}_{2012}=5, \mathrm{~N}_{2013}=5\right)$ to test the null hypothesis that offspring of parents sampled bi-weekly throughout the spawning season would show comparable survival and growth reaction norms when exposed to ambient $\left(\sim 600 \mu \mathrm{atm}, \mathrm{pH}_{\mathrm{NIST}}=8.07\right)$, elevated $\left(\sim 1100 \mu \mathrm{atm}, \mathrm{pH}_{\mathrm{NIST}}=7.77\right)$, and high $\mathrm{CO}_{2}$ levels $\left(\sim 2300 \mu \mathrm{atm}, \mathrm{pH}_{\mathrm{NIST}}=7.47\right)$ from fertilization to $10 \mathrm{~d}$ post hatch (dph).

\section{MATERIALS AND METHODS}

\section{Seasonal pH variability}

Seasonal $\mathrm{pH}$ conditions in the spawning habitat of Menidia menidia were quantified by using public monitoring data from Flax Pond $\left(40^{\circ} 57.78^{\prime} \mathrm{N}, 73^{\circ}\right.$ $8.22^{\prime} \mathrm{W}$; see Fig. S1 in the Supplement at www. int-res.com/articles/suppl/m504p001_supp.pdf), a protected tidal salt marsh $\left(\sim 1 \mathrm{~km}^{2}\right.$, mean tidal range = $1.8 \mathrm{~m})$ connected to Long Island Sound by a single inlet (Richard 1978). Starting in April 2008, FastResponse $\mathrm{pH}$ sensors mounted on a YSI ${ }^{\circledR} 6600$ sonde measured $\mathrm{pH}$ (National Institute of Standards and Technology [NIST], precision $=0.1$ units) in $6 \mathrm{~min}$ intervals approximately $0.5 \mathrm{~m}$ above sandy bottom in the main channel of the marsh (US Geological Survey, site \#01304057, http://ny.water.usgs.gov/rt/pub/ 01304057.html). Monthly routine maintenance on the device included cleaning, checks for biofouling and electronic drift, and recalibration (NIST) of sensors according to standard procedures described in USGS guidelines (Wagner et al. 2006). USGS funding con- straints disrupted pH monitoring in December 2012, thereby precluding direct comparisons of $\mathrm{pH}$ conditions in 2012 and 2013; instead, we characterized the long-term, average seasonal $\mathrm{pH}$ variability from data collected between April 2008 and November 2012 (n = 384664 observations). The $\mathrm{pH}$ minima, maxima, ranges, and means were calculated for each day of each year $(n=240)$ and later averaged across years. Linear regressions were used to estimate general seasonal trends in $\mathrm{pH}$ minima, maxima, ranges, and means between 15 February and 15 August (entire seasonal acidification) or between 1 April and 30 May (partial M. menidia spawning season). For an expanded analysis of Flax Pond monitoring data, see Baumann et al. (2014).

\section{$\mathrm{CO}_{2}$ treatments and measurements}

Following best practices guidelines for OA research (Riebesell et al. 2010), we used gas proportioning systems (ColeParmer ${ }^{\circledR}$ ) to mix air with $5 \%$ $\mathrm{CO}_{2}$ gas (ultra-pure grade) and delivered these mixes continuously via airstones to the bottom of each replicate rearing container. Three standardized treatment levels were administered during both years: ambient (air only, 2012: $670 \mu \mathrm{atm}, \mathrm{pH}_{\mathrm{NIST}}=8.04 ; 2013: 529 \mu \mathrm{atm}$, $\mathrm{pH}_{\text {NIST }}=8.10$ ), elevated (air: $\mathrm{CO}_{2}, 2012$ and 2013: 1100 patm, $\mathrm{pH}_{\mathrm{NIST}}=7.77$ ), and high $\mathrm{CO}_{2}$ conditions (air: $\mathrm{CO}_{2}, 2012$ and 2013: $2300 \mu \mathrm{atm}, \mathrm{pH}_{\mathrm{NIST}}=7.47$ ). While these treatments represent levels commonly used in OA experiments, they also depict conditions reached progressively during the $M$. menidia spawning season (Fig. 1A). Target $\mathrm{pH}$ levels were monitored daily using advanced $\mathrm{pH}$ probes (Durafet II, Honeywell; Orion ROSS Ultra pH/ATC Triode and Orion Star A121 pH Portable Meter, Thermo Scientific) that were regularly calibrated with 3-point NIST traceable $\mathrm{pH}_{\mathrm{NIST}}$ references. In addition, at least one discrete water sample per treatment was taken during each experiment (borosilicate bottles, preserved with $200 \mu \mathrm{l} \mathrm{HgCl}_{2}$ ) and analyzed for dissolved inorganic carbon (DIC, mol kg-1 seawater) with an EGM4 Environmental Gas Analyzer (for detailed descriptions, see Talmage \& Gobler 2010, Gobler et al. 2014). Actual levels of $\mathrm{CO}_{2}$ and total alkalinity were then calculated based on measured DIC, pH (NIST), temperature, salinity, and first and second dissociation constants of carbonic acid in seawater (Roy et al. 1993) using CO2SYS (http://cdiac.ornl.gov/ftp/co2sys/). A complete overview of carbonate chemistry measurements from all experiments can be found in Table $\mathrm{S} 1$ in the Supplement. 


\section{Field sampling and experimental design}

During both years, sampling for ripe adult $M$. menidia was conducted bi-weekly between the end of March and early July at Poquot Beach $\left(40^{\circ} 56.85^{\prime} \mathrm{N}\right.$, $\left.73^{\circ} 6.15^{\prime} \mathrm{W}\right)$, an accessible but otherwise identical tidal marsh compared to the adjacent Flax Pond ( $<4 \mathrm{~km}$ away, Fig. S1 in the Supplement). Specimens were caught with a $30 \mathrm{~m} \times 2 \mathrm{~m}$ beach seine, separated by sex, transported live to our laboratory facility, and held overnight in large aerated tanks $\left(21^{\circ} \mathrm{C}\right.$, ambient $\mathrm{CO}_{2}$, no food). On fertilization day (FD = collection day +1$)$, $\geq 20$ ripe individuals from each sex were strip-spawned onto window screens submerged in plastic dishes with clear seawater $1<20$ males were available for final experiments in 2012 and 2013). Strip-spawned adults were measured for standard length (SL, lower $0.5 \mathrm{~cm}_{i}$ Fig. S2 in the Supplement), which showed that seasonal variability in spawner SL was not correlated to survival or $1 \mathrm{dph}$ length (Pearson correlation, $\mathrm{p}>0.05$ ). Fertilized eggs quickly attached to window screens via chorionic filaments, which facilitated precise enumeration and distribution of embryos among replicates and treatments. Each experiment $\left(\mathrm{N}_{2012}=5, \mathrm{~N}_{2013}=5\right.$; Fig. 1B, Table S2 in the Supplement) consistently started within $2 \mathrm{~h}$ after fertilization with a random 100 embryos per replicate. Within the limits of available embryo numbers and laboratory constraints, we tried to maximize the number of replicates per treatment (generally 3 to 6; see Table S2). Following time-tried rearing methods for $M$. menidia offspring, replicate containers (20 l) were filled with aged, clean seawater from our facility's seawater well (25 psu) and then placed in large water baths (700 l) controlled for optimal temperature and light conditions $\left(24^{\circ} \mathrm{C}, 15 \mathrm{~h}\right.$ light:9 h dark; Middaugh et al. 1987). We note that optimal rearing temperatures yield highest growth and survival rates in the laboratory, irrespective of the lower temperatures in Long Island waters between April and July (Middaugh et al. 1987, this study). Larvae hatched $\sim 120 \mathrm{~h}$ post fertilization and were immediately provided with ad libitum rations of newly hatched brine shrimp nauplii Artemia salina (San Francisco strain, Brine Shrimp Direct) and a commercial larval powder food (first $2 \mathrm{dph}$, Otohime Marine Weaning Diet, size A, Reed Mariculture ${ }^{\circledR}$ ). At $1 \mathrm{dph}$, live larvae were counted by gently scooping small groups into replacement containers, while preserving a random subsample $(\mathrm{n}=10)$ in $10 \%$ formaldehyde/seawater solution for later SL measurements (nearest $0.01 \mathrm{~mm}$ ) via calibrated, digital images (ImagePro ${ }^{\circledR}$ V6.0). Between 1 to $10 \mathrm{dph}$, all containers were cleaned daily, and water was partially exchanged twice. All experiments were terminated at $10 \mathrm{dph}$, which brackets the most vulnerable early life period in M. menidia, and all survivors were counted, preserved, and later measured for SL. Two experiments in 2012 did not yield data because an unidentified hydrozoan infestation (early May) and an unusually low fertilization success (early June) caused near total mortality in all treatments post hatch. Survival (\%) was calculated from fertilization day (FD) to $1 \mathrm{dph}, 1$ to $10 \mathrm{dph}$, and FD to $10 \mathrm{dph}$; for clarity, we limited the presentation to the most important F to 10 dph interval (see Table S2 in the Supplement for other data). Growth ( $\mathrm{mm} \mathrm{d}^{-1}$ ) was calculated as the mean 1-10 dph SL difference for each replicate, divided by 9 d. Survival data were arcsine transformed prior to statistical comparisons. All statistical analyses (ANOVAs, GLMs) were conducted using IBM SPSS Statistics (v.20).

\section{RESULTS}

In both years, $\mathrm{CO}_{2}$ reaction norms in Menidia menidia offspring exhibited a seasonal plasticity (Table 1) that coincided with the natural acidification cycle in the species' spawning habitat (Fig. 1). Monitoring data revealed that the marsh's seasonal acidification begins shortly after reaching its annual $\mathrm{pH}$ maximum in mid-February, which is also the time of the least diel $\mathrm{pH}$ variability in the system (mean daily $\mathrm{pH}_{\min , \max }=8.05,8.28$ ). Between February and August, ecosystem respiration intensifies and elicits

Table 1. Effect of $\mathrm{CO}_{2}$ level (ambient, elevated, high), fertilization date (FD, both years combined) and their interaction on the survival ( $\%$, fertilization to $10 \mathrm{~d}$ post hatch, arcsine transformed) of Menidia menidia offspring during the first and second half of the spawning season (Fig. 1), using a general linear model. Significant $(\alpha<0.05) p$-values in bold

\begin{tabular}{|llccr|}
\hline $\begin{array}{l}\text { Spawning } \\
\text { period }\end{array}$ & $\begin{array}{l}\text { Source of } \\
\text { variation }\end{array}$ & df & $F$ & $\mathrm{p}$ \\
\hline April to mid-May & Model & 14 & 4.8 & $<\mathbf{0 . 0 0 1}$ \\
& Intercept & 1 & 879.0 & $<\mathbf{0 . 0 0 1}$ \\
& $\mathrm{CO}_{2}$ & 2 & 11.4 & $\mathbf{< 0 . 0 0 1}$ \\
& $\mathrm{FD}$ & 4 & 3.3 & $\mathbf{0 . 0 1 9}$ \\
& $\mathrm{CO}_{2} \times \mathrm{FD}$ & 8 & 2.9 & $\mathbf{0 . 0 0 9}$ \\
Mid-May to & $\mathrm{Model}_{\text {early July }}$ & 12 & 6.4 & $\mathbf{< 0 . 0 0 1}$ \\
& $\mathrm{Intercept}$ & 1 & 420.9 & $<\mathbf{0 . 0 0 1}$ \\
& $\mathrm{CO}_{2}$ & 2 & 1.0 & 0.367 \\
& $\mathrm{FD}$ & 4 & 16.0 & $<\mathbf{0 . 0 0 1}$ \\
& $\mathrm{CO}_{2} \times \mathrm{FD}$ & 6 & 0.9 & 0.494 \\
\hline
\end{tabular}



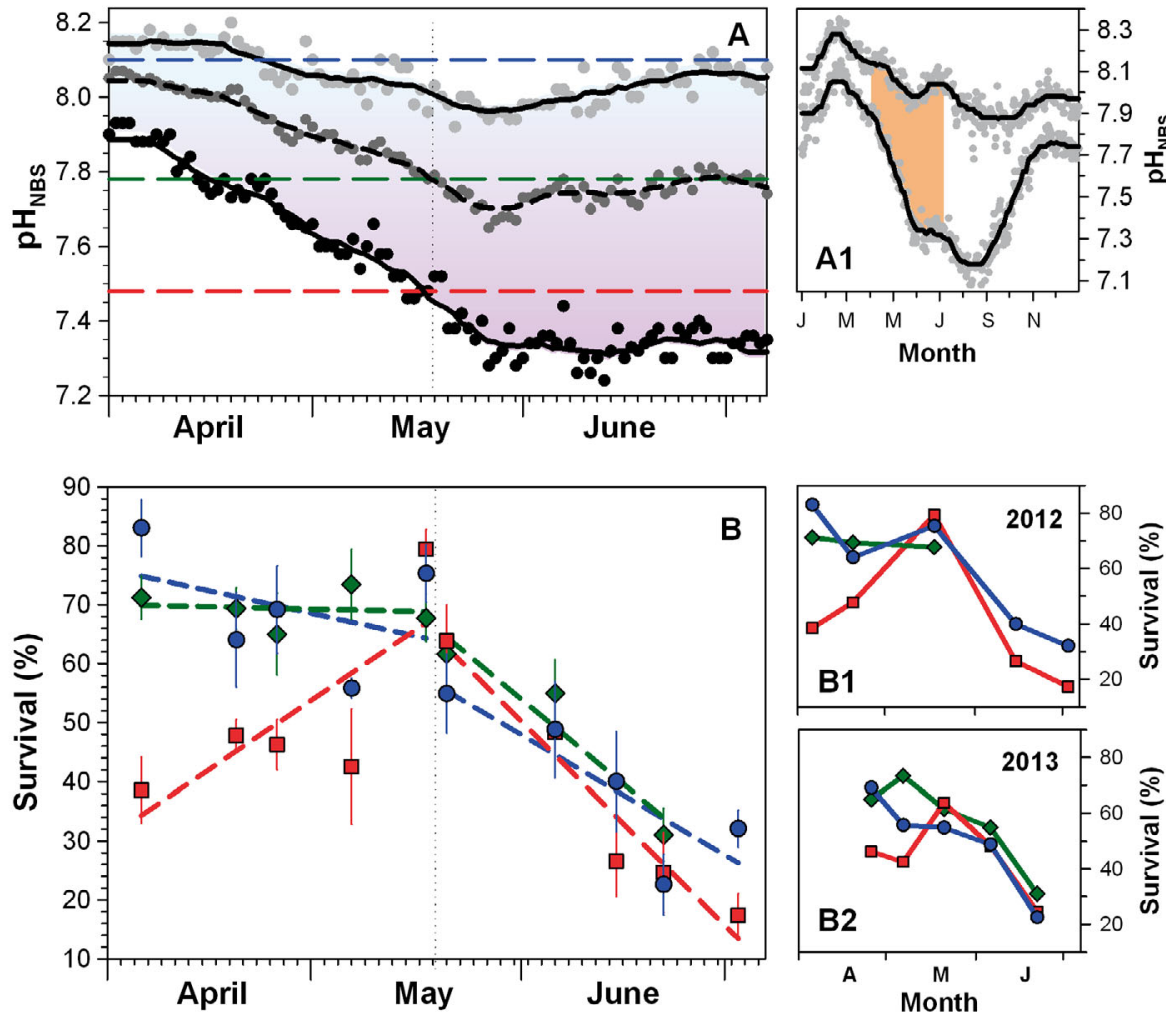

Fig. 1. Seasonal acidification in the spawning habitat of Menidia menidia and its correspondence to changes in offspring survival under different $\mathrm{CO}_{2}$ levels. (A) Five year (2008-2012) average daily $\mathrm{pH}$ minima, means, and maxima (black, dark grey, grey circles, respectively) in April, May, and June (A1: January to December minima, maxima; orange shading $=M$. menidia spawning season) at Flax Pond salt marsh, fitted with a moving median local smoother (bandwidth $=10 \%$ of data). Dashed lines depict experimental $\mathrm{pH}_{\mathrm{NIST}}$ levels. (B) $M$. menidia. Mean $( \pm 1 \mathrm{SE})$ survival of offspring reared from fertilization to $10 \mathrm{~d}$ post hatch at ambient (2012: $670 \mu \mathrm{atm}, \mathrm{pH}_{\mathrm{NIST}}=8.04 ; 2013: 530$ uatm, $\mathrm{pH}_{\mathrm{NIST}}=8.10$, blue circles), elevated $\left(\sim 1100 \mu\right.$ atm, $\mathrm{pH}_{\mathrm{NIST}}=7.77$, green diamonds), and high ( 2300 $\mu \mathrm{atm}$, $\mathrm{pH}_{\mathrm{NIST}}=7.47$, red squares) $\mathrm{CO}_{2}$ levels throughout the 2012 (see B1) and 2013 (see B2) spawning seasons. Dates correspond to the day of fertilization. Dashed lines represent linear fits to the combined data during the first and second half of the spawning season (marked by the dotted vertical line)

Ambient $\mathrm{CO}_{2}\left(\mathrm{pH} 8.04\right.$ - 8.10) Elevated $\mathrm{CO}_{2}(\mathrm{pH} 7.77) \quad$ High $\mathrm{CO}_{2}(\mathrm{pH} 7.47)$

a continuous decline in average $\mathrm{pH}$ at a rate of -0.003 units $\mathrm{d}^{-1}$ and a concomitant increase in diel $\mathrm{pH}$ fluctuations (+0.003 units $\mathrm{d}^{-1}$ ). In August, when the system is at its most extreme state, $\mathrm{pH}_{\mathrm{NIST}}$ fluctuates daily on average between 7.15 and 7.89 (mean $\mathrm{pH}_{\text {NIST }}=7.58$; Fig. 1). The steepest section of the annual pH decline, however, was consistently observed between April and the end of May (mean $\mathrm{pH}_{\min } 7.90 \rightarrow 7.30,-0.01$ units $\mathrm{d}^{-1}$; mean $\mathrm{pH}_{\max }$ $8.05 \rightarrow 7.94,-0.004$ units $d^{-1}$; Fig. 1A), which corresponds to the first half of $M$. menidia's spawning season. Hence, offspring born early in the season experience predictably higher and less variable $\mathrm{pH}$ conditions than their later-born conspecifics.

In the laboratory, offspring spawned from the first collections of ripe adults were highly sensitive to increased $\mathrm{CO}_{2}$ levels (Fig. 1B). During the first experiment in 2012 (fertilized 6 April), survival (mean \pm SE) declined significantly (ANOVA, $F_{2,6}=20.4, \mathrm{p}=$ $0.002)$ from ambient $(83 \pm 5 \%)$ to elevated $(71 \pm 4 \%)$ and high (39 $\pm 6 \%) \mathrm{CO}_{2}$ treatments. Similarly, a significant (ANOVA, $\left.F_{2,18}=4.4, \mathrm{p}=0.028\right) \mathrm{CO}_{2}$ effect was observed during the first experiment in 2013, when survival decreased from ambient (69 $\pm 7 \%$ ) and elevated $\left(65 \pm 7 \%\right.$ ) to high $\mathrm{CO}_{2}$ conditions (46 \pm $4 \%$ ). However, trials rearing offspring from adults collected at the same site later in the season did not reproduce this linear pattern. During each year's second experiment, high $\mathrm{CO}_{2}$ conditions still elicited the lowest survival, while survival at elevated $\mathrm{CO}_{2}$ treatments slightly exceeded ambient values $(\mathrm{p}>0.05$; Fig. 1B). In contrast, offspring from parents collected in mid-May showed high overall survival rates that did not differ significantly among $\mathrm{CO}_{2}$ treatments (Fig. 1B). Hence, during the first half of the spawning season (April to mid-May), survival at high $\mathrm{CO}_{2}$ conditions increased significantly from 39 to $79 \%$ ( $p=$ 0.002; Fig. 1B, Table 2), whereas survival at ambient and elevated $\mathrm{CO}_{2}$ treatments remained high, thereby resulting in the rapid equilibration in offspring survival across $\mathrm{CO}_{2}$ treatments (Fig. 1B, Table 2). Interestingly, during the second half of the spawning season (mid-May to early July), we observed a steady decline in survival irrespective of $\mathrm{CO}_{2}$ treatment, resulting in very low offspring survival from parents spawned at the end of June and early July (17 to $31 \%$; Fig. 1B).

A general linear model (GLM) was constructed for each half of the spawning season to test for the effects of $\mathrm{CO}_{2}$ level, fertilization date (FD), and the $\mathrm{CO}_{2} \times \mathrm{FD}$ interaction on survival (combined years; Table 1). During the first period, $\mathrm{CO}_{2}, \mathrm{FD}$, and their interaction were significant (model $\mathrm{R}^{2}$ adj $=0.46, \mathrm{p}<$ 0.05; Table 1), the latter confirming the statistically 
Table 2. Menidia menidia offspring survival (\%, fertilization to $10 \mathrm{~d}$ post hatch) as a linear function of fertilization date (2012 and 2013 combined) during the first and second half of the spawning season (Fig. 1). Significant $(\alpha<0.05)$ $\mathrm{p}$-values in bold

\begin{tabular}{|llccc|}
\hline Spawning period & $\mathrm{CO}_{2}$ level & $\mathrm{df}$ & $\mathrm{p}$ & Slope \\
\hline April to mid-May & Ambient & 1 & 0.570 & - \\
& Elevated & 1 & 0.838 & - \\
& High & 1 & $\mathbf{0 . 0 0 2}$ & + \\
Mid-May to & Ambient & 1 & $\mathbf{0 . 0 0 2}$ & - \\
early July & Elevated & 1 & $\mathbf{0 . 0 0 2}$ & - \\
& High & 1 & $\mathbf{< 0 . 0 0 1}$ & - \\
\hline
\end{tabular}

divergent survival responses at ambient, elevated, and high $\mathrm{CO}_{2}$ levels over time. During the second period, however, only FD remained a significant predictor of survival $(p<0.001$; Table 1$)$, whereas $\mathrm{CO}_{2}$ and $\mathrm{CO}_{2} \times \mathrm{FD}$ were not, expressing the $\mathrm{CO}_{2}-$ independent decline in overall survival during both years.

Length (SL, $1 \mathrm{dph}$ ) of newly hatched $M$. menidia offspring varied between 4.6 and $6.3 \mathrm{~mm}$ (mean $\pm \mathrm{SD}$ $=5.4 \pm 0.4 \mathrm{~mm}$ ) and showed a significant decrease throughout the entire spawning season $(\mathrm{p}<0.001$; Table 3). Given the overall variability, there was no detectable effect of increasing $\mathrm{CO}_{2}$ levels on length at $1 \mathrm{dph}$ (Fig. 2A). Growth rates (1 to $10 \mathrm{dph}$ ) were significantly reduced by increasing $\mathrm{CO}_{2}$ during the first experiment in April 2012 (ANOVA, $F_{2,6}=11.7$, $\mathrm{p}<0.008$ ) but not in April 2013 or in May $(2012$ and 2013) and thereafter, when growth rates declined independently of $\mathrm{CO}_{2}$ level (Fig. 2B). A GLM testing for effects of $\mathrm{CO}_{2}$, Month, and the $\mathrm{CO}_{2} \times$ Month interaction confirmed the highly significant influence of Month and the small, overall non-significant effects of $\mathrm{CO}_{2}$ and the $\mathrm{CO}_{2} \times$ Month interaction (Table 3).
Table 3. Effects of $\mathrm{CO}_{2}$ level (ambient, elevated or high), month (month of fertilization, both years combined) and their interaction on growth ( $\mathrm{mm} \mathrm{d}^{-1}, 1$ to $10 \mathrm{~d}$ post hatch) of Menidia menidia larvae during the 2012 and 2013 spawning seasons, analyzed using a general linear model. Significant $(\alpha<0.05) \mathrm{p}$-values in bold

\begin{tabular}{|lccr|}
\hline Source of variation & df & $F$ & \multicolumn{1}{c|}{$\mathrm{p}$} \\
\hline Model & 10 & 4.4 & $<\mathbf{0 . 0 0 1}$ \\
Intercept & 1 & 2383.4 & $<\mathbf{0 . 0 0 1}$ \\
$\mathrm{CO}_{2}$ & 2 & 1.7 & 0.190 \\
Month & 3 & 11.5 & $<\mathbf{0 . 0 0 1}$ \\
$\mathrm{CO}_{2} \times$ Month & 5 & 1.8 & 0.120 \\
\hline
\end{tabular}

\section{DISCUSSION}

This study produced novel evidence for direct $\mathrm{CO}_{2}$ related survival reductions and, to a lesser extent, growth reductions during the early life stages of Menidia menidia, a widely abundant and ecologically important forage fish species along the USA Atlantic coast. In addition, it also documented, to our knowledge for the first time in a marine organism, an interannually consistent, seasonal change in offspring $\mathrm{CO}_{2}$ sensitivities. By combining repetitive field sampling of spawning adults with standardized short-term exposure experiments and parallel environmental monitoring, we showed how the rapid shift from $\mathrm{CO}_{2}$-sensitive to $\mathrm{CO}_{2}$-tolerant offspring coincided temporally with the seasonal acidification in the species' spawning habitat. To the observer, it appeared as if offspring could 'anticipate' the $\mathrm{pH}$ and $\mathrm{CO}_{2}$ environment they were about to enter. The clear survival benefit of this plasticity suggests that it is adaptive and comprises some form of parental conditioning, by which spawning adults modify offspring $\mathrm{CO}_{2}$ reaction norms based on their environmental

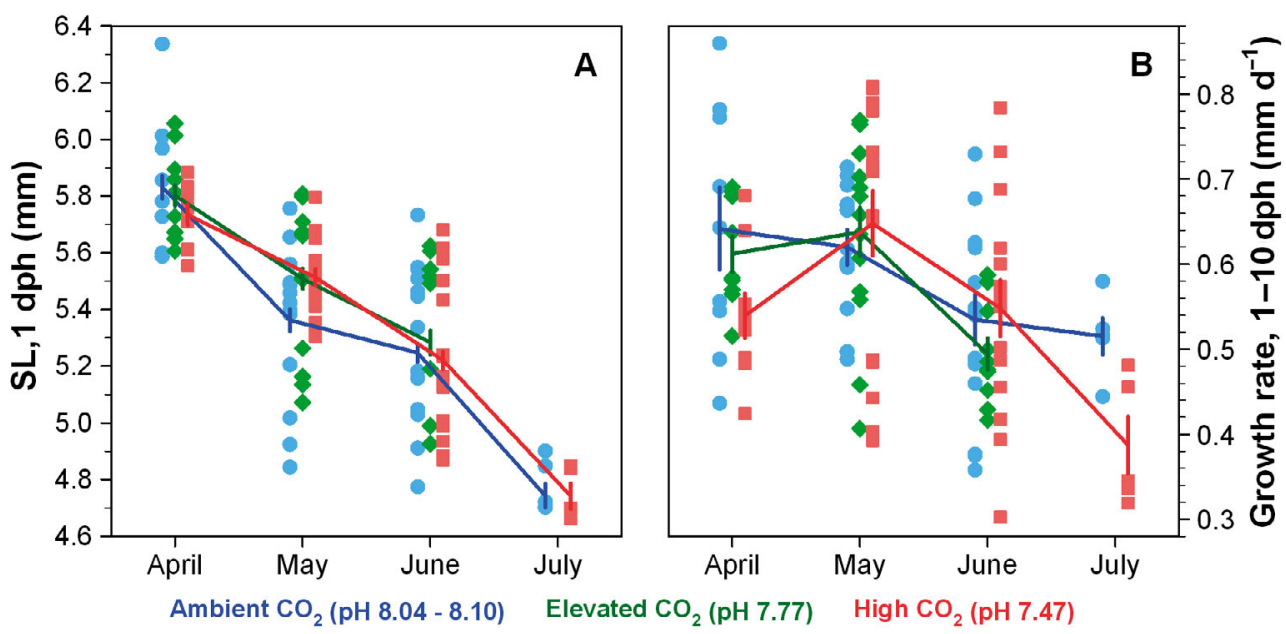

Fig. 2. Menidia menidia. Seasonal variability in (A) standard length (SL, $1 \mathrm{~d}$ post hatch [dph]) and (B) SL growth rate $(1-10 \mathrm{dph})$ of offspring reared from fertilization to $10 \mathrm{dph}$ at ambient (2012: 670 patm, $\mathrm{pH}_{\mathrm{NIST}}=$ 8.04; 2013: $530 \mu a t m, \mathrm{pH}_{\mathrm{NIST}}$ = 8.10, blue circles), elevated $(\sim 1100$ Hatm, $\mathrm{pH}=$ 7.77, green diamonds), and high $\mathrm{CO}_{2}$ levels $(\sim 2300 \mu \mathrm{atm}$, $\mathrm{pH}=7.47$, red squares). Symbols depict replicate means, while lines intersect monthly means $( \pm 1 \mathrm{SE})$ 
experience (Jablonka \& Raz 2009). This interpretation is supported by previous studies that demonstrated exactly this parent-offspring link in the laboratory (Miller et al. 2012, Parker et al. 2012), hypothesizing that it benefits organisms experiencing variable $\mathrm{CO}_{2}$ environments. More broadly, it is also consistent with the ubiquity of transgenerational effects found in many other traits (e.g. temperaturedependent growth: Donelson et al. 2012, Hurst et al. 2012, Salinas \& Munch 2012) and in taxonomically diverse organisms that thrive in highly variable environments (Jablonka \& Raz 2009, Salinas et al. 2013).

Neither the mechanisms responsible for direct $\mathrm{CO}_{2} / \mathrm{pH}$-related survival reductions nor those modifying $\mathrm{CO}_{2}$ sensitivity in fish offspring are presently well understood. Reduced survival at high $\mathrm{CO}_{2}$, as seen in $M$. menidia early in the season, might be a consequence of direct acidosis (Esbaugh et al. 2012), resulting from still ineffective ion exchanges via gills, ineffective acid-base regulation, and the still large surface-to-volume ratio of fish early life stages. Alternatively, countering internal $\mathrm{CO}_{2}$ increases may be possible but metabolically expensive (Rombough 2007), which entails faster depletion of energy reserves and thus a higher risk of starvation during the critical transition from yolk- to first-feeding larvae. This is consistent with our former study of $M$. beryllina, where survival reductions were found to be primarily a consequence of embryonic $\mathrm{CO}_{2}$ exposure, even though they manifested post hatch (Baumann et al. 2012).

With respect to seasonal changes in offspring $\mathrm{CO}_{2}$ tolerance, several alternative explanations are available. Theoretically, the pattern could be elicited by genetically different populations spawning at different times of the year. This is contradicted, however, by the species' semelparous, batch-spawning life history (Conover \& Kynard 1984) as well as by empirical data, which indicate that adults overwintering in coastal shelf waters move in spring as a single population into coastal and estuarine spawning habitats, where they remain until death (Conover \& Ross 1982). Hence, our approach likely monitored the same adult spawning population throughout the season, during which it experienced the progressively more variable and acidic environment while ripening batches of eggs with semi-lunar periodicity (Conover \& Kynard 1984). Sensing this environmental dynamic might trigger non-genetic gamete modifications via 2 main pathways: epigenetic inheritance and/or maternal provisioning.

Epigenetic mechanisms control DNA expression by a number of potential processes (e.g. DNA methylation, repressive histone modification: Chinnusamy
\& Zhu 2009), which could promote or suppress the transcription of key enzymes involved in acid-base regulation or mitochondrial metabolism (Esbaugh et al. 2012). For example, acclimation of adult eelpout Zoarces viviparous to environmental hypercapnia was shown to involve initial downregulation but then upregulation of the key ion transporters $\left(\mathrm{Na}^{+} / \mathrm{HCO}_{3}{ }^{-}\right.$ and $\mathrm{Cl}^{-} / \mathrm{HCO}_{3}^{-}$) involved with acid-base regulation in the gills (Deigweiher et al. 2008). Such transcriptomic plasticity has been detected in fish larvae as well. Zebrafish Danio rerio embryos increased the quantity and size of epidermal $\mathrm{H}^{+}$-ATPase-rich cells when exposed to low pH water (Horng et al. 2009), while larvae of Japanese ricefish (medaka, Oryzias latipes) could up-regulate several acid-base relevant genes when exposed to hypercapnia (Tseng et al. 2013). Epigenetic inheritance of a specific transcriptomic configuration (e.g. corresponding to low vs. high $\mathrm{CO}_{2}$ levels) could plausibly enhance physiological performance immediately after fertilization and hence increase the probability of survival for offspring entering highly variable environments. This is a rich field for future discoveries, as detailed transcriptomic and genomic approaches are increasingly used to further examine the mechanisms and ecological significance of epigenetic inheritance. Another question is what exposure time parents need to successfully condition their offspring to a different environment. Trials in anemonefish Amphiprion melanopus exposed parents to high $\mathrm{CO}_{2}$ levels for $2 \mathrm{mo}$ before spawning (Miller et al. 2012), whereas offspring reaction norms in $M$. menidia changed from one biweekly spawning event to the next (this study).

Maternal provisioning comprises an alternative mechanism to potentially alter offspring $\mathrm{CO}_{2}$ reaction norms. Increases in egg yolk lipids, for example, could enable embryos to meet the higher metabolic demands in physiologically more stressful environments. During this study, we did not observe any obvious seasonal changes in e.g. egg size, color, or number of oil globules; however, targeted microscopic or energetic measurements are needed to further support or discount such maternal effects. This would also help to elucidate a different, $\mathrm{CO}_{2}$ unrelated, but no less intriguing pattern observed during our experiment, i.e. the steady decline in survival and growth during the second half of each year's spawning season. A plausible, yet to be tested explanation might be that adult energy reserves, and with them the quality of egg batches, deteriorate (Trippel 1998) toward the end of the spawning season that concludes this species' annual life cycle. 
While the general pattern of seasonally increasing offspring tolerance to $\mathrm{CO}_{2}$ was consistent between years, there were also noteworthy differences. The arrival and disappearance of ripe adults in our beach seines suggested that the spawning season in 2012 started 3 wk earlier and ended 2 wk later than in 2013 (Fig. 1B). Provided that the annual ingress of adult $M$. menidia into their nearshore spawning habitat is cued by temperature (Conover \& Ross 1982), the earlier arrival of adult $M$. menidia was likely caused by notably warmer spring temperatures in coastal waters in 2012 relative to 2013 (Fig. 3). How this thermal difference translated into seasonal $\mathrm{pH}$ differences is unknown; however, temperature data (Fig. 3) and survival reaction norms (Fig. 1B) suggested a lag in environmental acidification of approximately 2 wk in 2013 relative to 2012. In addition, robustly inferring transgenerational plasticity in offspring $\mathrm{CO}_{2}$ tolerance requires experimental manipulations of parental spawning conditions. This was attempted, but our approach to hold adults in the laboratory for 6 wk after collection (following Miller et al. 2012) did not yield sufficient egg quantities. Lastly, our approach to provide larvae with ad libitum food rations, albeit practical, might have obscured potential $\mathrm{CO}_{2}$-related growth effects in feeding larvae. Consistent with Menidia beryllina (Baumann et

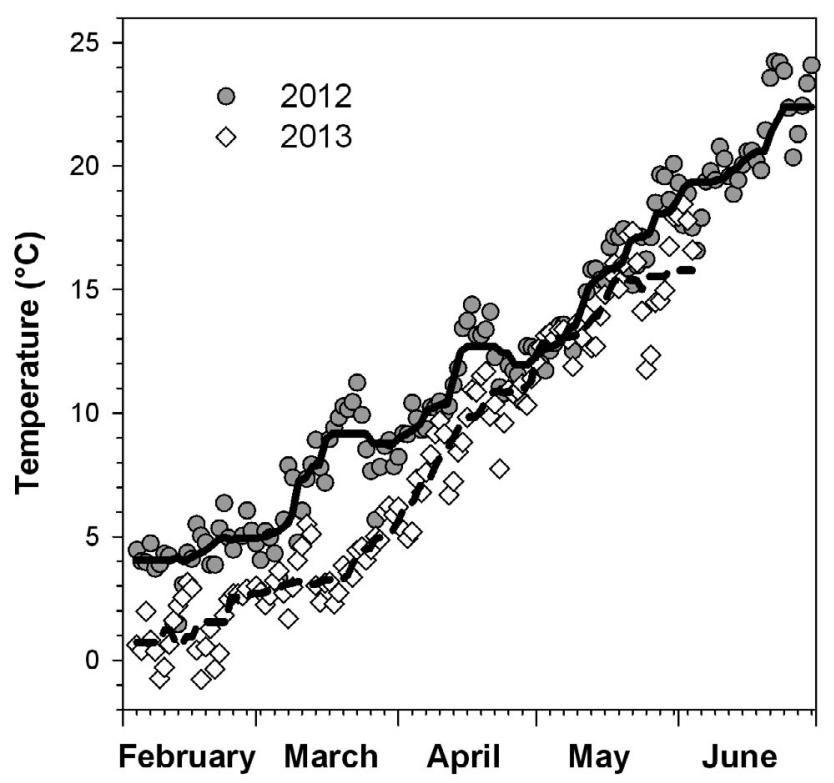

Fig. 3. Mean daily water temperature at the Flax Pond salt marsh in spring 2012 (grey circles) and 2013 (white diamonds), measured in the main channel $\sim 0.5 \mathrm{~m}$ above the bottom (US Geological Survey monitoring site \#01304057, http://ny.water.usgs.gov/rt/pub/01304057.html). Black solid and dashed lines represent non-parametric, running median local fits (band width $=10 \%$ of the data) al. 2012), we found a significant decrease in M. menidia post-hatch growth with increasing $\mathrm{CO}_{2}$ levels; however, this pattern was limited to the first experiment in 2012. Assuming that high $\mathrm{CO}_{2}$ environments primarily impose additional energetic costs in larval fish, survivors of these treatments might have simply met these costs by increased food consumption. This could also explain the mostly neutral or positive growth effects of increasing $\mathrm{CO}_{2}$ levels reported by other studies on fish early life stages (Munday et al. 2009b, Frommel et al. 2012b, Bignami et al. 2013, Chambers et al. 2013, Hurst et al. 2013).

Assessing marine species vulnerabilities to anthropogenic changes in ocean chemistry remains the core motivation for most ocean acidification research (Denman et al. 2011, Branch et al. 2013). Our discovery of seasonally shifting $\mathrm{CO}_{2}$ sensitivities in fish offspring has complicated this task further. For example, the majority of empirical data available to date has come from species chosen opportunistically based on research groups' prior expertise and feasibility considerations. Particularly for early life stages, feasible experiments often rely on adult broodstocks kept in aquaculture or research facilities, where ambient conditions (light, temperature, pH, and food) are unlikely to resemble the environment experienced by wild populations. Given the mounting evidence for transgenerational plasticity in many traits including offspring $\mathrm{CO}_{2}$ tolerance, such experiments will continue to generate valuable mechanistic insights but are likely of limited value for inferring species vulnerabilities to ocean acidification. A case in point, we previously used offspring from a large, genetically diverse, commercial broodstock of $M$. beryllina and found that early life survival and growth decreased by 74 and $18 \%$, respectively, in direct response to increases from ambient ( 400 $\mu \mathrm{atm})$ to elevated ( 1000 $\mu \mathrm{atm}) \mathrm{CO}_{2}$ levels (Baumann et al. 2012). In the present study, wild $M$. menidia offspring were largely insensitive to $\sim 1100 \mu \mathrm{atm} \mathrm{CO}_{2}$, while showing survival reductions of $54 \%$ (2012, first experiment) and $33 \%$ (2013, first experiment) in response to high ( 2300 $\mu \mathrm{atm})$ relative to ambient $\mathrm{CO}_{2}$ levels. Whether these differences merely reflect speciesspecific $\mathrm{CO}_{2}$ sensitivities requires further study.

Consistent with a growing number of publications, our study highlighted the importance of diel and seasonal $\mathrm{CO}_{2}$ fluctuations that many ecologically and economically important organisms regularly experience in coastal habitats (Hendriks et al. 2010, Hofmann et al. 2011, McElhany \& Busch 2012, Duarte et al. 2013). Tidal salt marshes constitute the dominant intertidal habitat along the USA east coast 
and the Gulf of Mexico (Pennings \& Bertness 2001) and, given their high productivity (Wang \& Cai 2004), likely host extreme $\mathrm{CO}_{2}$ fluctuations. At our study site, the average $\mathrm{pH}$ decline between 15 February and 15 August (-0.55 units) annually exceeded the predictions for average open ocean acidification within the next 200 yr (Caldeira \& Wickett 2003). In late summer, observed diel $\mathrm{CO}_{2}$ fluctuations (400 to 4000 atm; Baumann et al. 2014) resulting from interacting tidal and day-night cycles in the marsh were about twice the magnitude of the predicted maximum acidification in the average open ocean (Caldeira \& Wickett 2003). While our study suggests that $M$. menidia adults and offspring have adapted to these current fluctuations, many anthropogenic processes could synergistically exacerbate $\mathrm{pH}$, temperature, and $\mathrm{O}_{2}$ variability in coastal habitats in the future (Hofmann \& Todgham 2010, Gobler et al. 2014), thereby challenging even species like the Atlantic silverside. Finally, the spatial heterogeneity of acidification in estuaries is poorly understood, yet potentially large $\mathrm{pH}$ differences in adult and offspring habitats could significantly impact the success of a given cohort of fish.

In summary, our study suggests that transgenerational acclimation to increasing $\mathrm{CO}_{2}$ levels is not just a laboratory phenomenon but likely comprises a common adaptive strategy in marine fish and other organisms coping with the biologically driven, natural $\mathrm{pH}$ and $\mathrm{CO}_{2}$ variability in coastal habitats. Our results imply that realistic, experimental assessments of species vulnerabilities to ocean acidification (and other stressors) will require more comprehensive approaches that control or account for parental environments (Miller et al. 2012, Parker et al. 2012, Reusch 2014).

Acknowledgements. We thank Chris Schubert and Tristen Tagliaferri from the USGS for facilitating the study. Funding for maintaining USGS site \# 01304057 also comes from the New York State Department of Environmental Conservation (NYSDEC) and the Nature Conservancy. The National Science Foundation provided full funding for C.M. and A.M. and partial funding for H.B. and C.G. (NSF \#1129622). C.G. was also partially funded by the NOAA Ocean Acidification Program through award \#NA12NOS4780148 from the National Centers for Coastal Ocean Science and the Chicago Community Trust.

\section{LITERATURE CITED}

Baumann H, Talmage SC, Gobler CJ (2012) Reduced early life growth and survival in a fish in direct response to increased carbon dioxide. Nature Clim Chang 2:38-41

Baumann H, Wallace R, Tagliaferri T, Gobler CJ (2014) Large natural $\mathrm{pH}, \mathrm{CO}_{2}$ and $\mathrm{O}_{2}$ fluctuations in a temper- ate tidal salt marsh on diel, seasonal and interannual time scales. Estuar Coast (in press), doi:10.1007/s12237014-9800-y

> Bignami S, Enochs IC, Manzello DP, Sponaugle S, Cowen RK (2013) Ocean acidification alters the otoliths of a pantropical fish species with implications for sensory function. Proc Natl Acad Sci USA 110:7366-7370

Branch TA, DeJoseph BM, Ray LJ, Wagner CA (2013) Impacts of ocean acidification on marine seafood. Trends Ecol Evol 28:178-186

Cai WJ, Hu X, Huang WJ, Murrell MC and others (2011) Acidification of subsurface coastal waters enhanced by eutrophication. Nature Geosci 4:766-770

Caldeira K, Wickett ME (2003) Anthropogenic carbon and ocean $\mathrm{pH}$. Nature 425:365

Chambers RC, Candelmo AC, Habeck EA, Poach ME and others (2013) Ocean acidification effects in the early lifestages of summer flounder, Paralichthys dentatus. Biogeosciences Discuss 10:13897-13929

Checkley DM, Dickson AG, Takahashi M, Radich JA, Eisenkolb N, Asch R (2009) Elevated $\mathrm{CO}_{2}$ enhances otolith growth in young fish. Science 324:1683

Chinnusamy V, Zhu JK (2009) Epigenetic regulation of stress responses in plants. Curr Opin Plant Biol 12:133-139

> Conover DO, Kynard BE (1984) Field and laboratory observations of spawning periodicity and behavior of a northern population of the Atlantic silverside, Menidia menidia (Pisces: Atherinidae). Environ Biol Fishes 11:161-171

Conover DO, Ross MR (1982) Patterns in seasonal abundance, growth and biomass of the Atlantic silverside, Menidia menidia, in a New England estuary. Estuaries 5: 275-286

> Deigweiher K, Koschnick N, Pörtner HO, Lucassen M (2008) Acclimation of ion regulatory capacities in gills of marine fish under environmental hypercapnia. Am J Physiol Regul Integr Comp Physiol 295:R1660-R1670

> Denman K, Christian JR, Steiner N, Pörtner HO, Nojiri Y (2011) Potential impacts of future ocean acidification on marine ecosystems and fisheries: current knowledge and recommendations for future research. ICES J Mar Sci 68: 1019-1029

> Dixson DL, Munday PL, Jones GP (2010) Ocean acidification disrupts the innate ability of fish to detect predator olfactory cues. Ecol Lett 13:68-75

> Donelson JM, Munday PL, McCormick MI, Pitcher CR (2012) Rapid transgenerational acclimation of a tropical reef fish to climate change. Nature Clim Chang 2:30-32

Doney SC, Fabry VJ, Feely RA, Kleypas JA (2009) Ocean acidification: the other $\mathrm{CO}_{2}$ problem. Annu Rev Mar Sci $1: 169-192$

> Duarte CM, Hendriks IE, Moore TS, Olsen YS and others (2013) Is ocean acidification an open-ocean syndrome? Understanding anthropogenic impacts on seawater $\mathrm{pH}$. Estuar Coast 36:221-236

> Dupont S, Havenhand J, Thorndyke W, Peck L, Thorndyke MC (2008) Near-future level of $\mathrm{CO}_{2}$-driven ocean acidification radically affects larval survival and development in the brittlestar Ophiothrix fragilis. Mar Ecol Prog Ser 373:285-294

> Dupont S, Dorey N, Stumpp M, Melzner F, Thorndyke M (2013) Long-term and trans-life-cycle effects of exposure to ocean acidification in the green sea urchin Strongylocentrotus droebachiensis. Mar Biol 160:1835-1843

Esbaugh AJ, Heuer R, Grosell M (2012) Impacts of ocean acidification on respiratory gas exchange and acid-base 
balance in a marine teleost, Opsanus beta. J Comp Physiol B 182:921-934

- Feely RA, Sabine CL, Hernandez-Ayon JM, Ianson D, Hales B (2008) Evidence for upwelling of corrosive 'acidified' water onto the continental shelf. Science 320:1490-1492

Franke A, Clemmesen C (2011) Effect of ocean acidification on early life stages of Atlantic herring (Clupea harengus L.). Biogeosciences 8:3697-3707

Frommel A, Schubert A, Piatkowski U, Clemmesen C (2012a) Egg and early larval stages of Baltic cod, Gadus morhua, are robust to high levels of ocean acidification. Mar Biol 160:1825-1834

- Frommel AY, Maneja R, Lowe D, Malzahn AM and others (2012b) Severe tissue damage in Atlantic cod larvae under increasing ocean acidification. Nature Clim Chang 2:42-46

> Gobler CJ, Depasquale E, Griffith A, Baumann H (2014) Hypoxia and acidification have additive and synergistic negative effects on the growth, survival, and metamorphosis of early life stage bivalves. PLoS ONE 9:e83648

Gooding RA, Harley CDG, Tang E (2009) Elevated water temperature and carbon dioxide concentration increase the growth of a keystone echinoderm. Proc Natl Acad Sci USA 106:9316-9321

> Hendriks IE, Duarte CM, Álvarez M (2010) Vulnerability of marine biodiversity to ocean acidification: a metaanalysis. Estuar Coast Shelf Sci 86:157-164

> Hofmann GE, Todgham AE (2010) Living in the now: physiological mechanisms to tolerate a rapidly changing environment. Annu Rev Physiol 72:127-145

> Hofmann GE, Smith JE, Johnson KS, Send U and others (2011) High-frequency dynamics of ocean pH: a multiecosystem comparison. PLoS ONE 6:e28983

Horng JL, Lin LY, Hwang PP (2009) Functional regulation of $\mathrm{H}^{+}$-ATPase-rich cells in zebrafish embryos acclimated to an acidic environment. Am J Physiol Cell Physiol 296: C682-C692

> Hurst TP, Munch SB, Lavelle KA (2012) Thermal reaction norms for growth vary among cohorts of Pacific cod (Gadus macrocephalus). Mar Biol 159:2173-2183

> Hurst TP, Fernandez ER, Mathis JT (2013) Effects of ocean acidification on hatch size and larval growth of walleye pollock (Theragra chalcogramma). ICES J Mar Sci 70: 812-822

Ishimatsu A, Hayashi M, Kikkawa T (2008) Fishes in high$\mathrm{CO}_{2}$, acidified oceans. Mar Ecol Prog Ser 373:295-302

Jablonka E, Raz G (2009) Transgenerational epigenetic inheritance: prevalence, mechanisms, and implications for the study of heredity and evolution. Q Rev Biol 84: 131-176

Kleypas JA, Feely RA, Fabry VJ, Langdon C, Sabine CL, Robbins LL (2006) Impacts of ocean acidification on coral reefs and other marine calcifiers: a guide for future research. Report of a workshop held 18-20 April 2005, St Petersburg, FL, sponsored by NSF, NOAA, and the US Geological Survey

Kurihara $\mathrm{H}$ (2008) Effects of $\mathrm{CO}_{2}$-driven ocean acidification on the early developmental stages of invertebrates. Mar Ecol Prog Ser 373:275-284

McElhany P, Busch DS (2012) Appropriate $\mathrm{pCO}_{2}$ treatments in ocean acidification experiments. Mar Biol 160: 1807-1812

Melzner F, Thomsen J, Koeve W, Oschlies A and others (2012) Future ocean acidification will be amplified by hypoxia in coastal habitats. Mar Biol 160:1875-1888
Middaugh DP, Hemmer MJ, Goodman LR (1987) Methods for spawning, culturing and conducting toxicity-tests with early life stages of four atherinid fishes: the inland silverside, Menidia beryllina, Atlantic silverside, $M$. menidia, tidewater silverside, $M$. peninsulae and California grunion, Leuresthes tenuis. U.S. Environmental Protection Agency, Washington, DC

> Miller GM, Watson SA, Donelson JM, McCormick MI, Munday PL (2012) Parental environment mediates impacts of increased carbon dioxide on a coral reef fish. Nature Clim Chang 2:858-861

> Munday PL, Dixson DL, Donelson JM, Jones GP, Pratchett MS, Devitsina GV, Døving KB (2009a) Ocean acidification impairs olfactory discrimination and homing ability of a marine fish. Proc Natl Acad Sci USA 106:1848-1852

Munday PL, Donelson JM, Dixson DL, Endo GGK (2009b) Effects of ocean acidification on the early life history of a tropical marine fish. Proc R Soc Lond B 276:3275-3283

Munday PL, Gagliano M, Donelson JM, Dixson DL, Thorrold SR (2011) Ocean acidification does not affect the early life history development of a tropical marine fish. Mar Ecol Prog Ser 423:211-221

> Nilsson GE, Dixson DL, Domenici P, McCormick MI, Sorensen C, Watson SA, Munday PL (2012) Near-future carbon dioxide levels alter fish behaviour by interfering with neurotransmitter function. Nature Clim Chang 2: 201-204

> Parker LM, Ross PM, O'Connor WA, Borysko L, Raftos DA, Pörtner HO (2012) Adult exposure influences offspring response to ocean acidification in oysters. Glob Change Biol 18:82-92

Pennings SC, Bertness MD (2001) Salt marsh communities. In: Bertness MD, Gaines SD, Hay M (eds) Marine community ecology. Sinauer, Sunderland, MA

$>$ Reusch TBH (2014) Climate change in the oceans: evolutionary versus phenotypically plastic responses of marine animals and plants. Evol Appl 7:104-122

Richard GA (1978) Seasonal and environmental variations in sediment accretion in a Long Island salt marsh. Estuaries 1:29-35

Riebesell U, Fabry VJ, Hansson L, Gattuso JP (2010) Guide to best practices for ocean acidification research and data reporting. Publications Office of the European Union, Luxembourg

Ries JB, Cohen AL, McCorkle DC (2009) Marine calcifiers exhibit mixed responses to $\mathrm{CO}_{2}$-induced ocean acidification. Geology 37:1131-1134

$>$ Rombough P (2007) The functional ontogeny of the teleost gill: Which comes first, gas or ion exchange? Comp Biochem Physiol A 148:732-742

Roy RN, Roy LN, Vogel KM, Porter-Moore C and others (1993) The dissociation constants of carbonic acid in seawater at salinities 5 to 45 and temperatures 0 to $45^{\circ} \mathrm{C}$. Mar Chem 44:249-267

Salinas S, Munch SB (2012) Thermal legacies: transgenerational effects of temperature on growth in a vertebrate. Ecol Lett 15:159-163

Salinas S, Brown SC, Mangel M, Munch SB (2013) Nongenetic inheritance and changing environments. NonGenetic Inheritance 1:38-50

> Salisbury J, Green M, Hunt C, Campbell J (2008) Coastal acidification by rivers: a new threat to shellfish? Eos Trans Am Geophys Union 89:513

Seibel BA, Maas AE, Dierssen HM (2012) Energetic plasticity underlies a variable response to ocean acidification 
in the pteropod, Limacina helicina antarctica. PLoS ONE 7:e30464

Talmage SC, Gobler CJ (2010) Effects of past, present, and future ocean carbon dioxide concentrations on the growth and survival of larval shellfish. Proc Natl Acad Sci USA 107:17246-17251

Trippel EA (1998) Egg size and viability and seasonal offspring production of young Atlantic Cod. Trans Am Fish Soc 127:339-359

Tseng YC, Hu MY, Stumpp M, Lin LY, Melzner F, Hwang PP (2013) $\mathrm{CO}_{2}$-driven seawater acidification differentially affects development and molecular plasticity along life history of fish (Oryzias latipes). Comp Biochem Physiol A 165:119-130

Editorial responsibility: Paul Snelgrove,

St. John's, Newfoundland and Labrador, Canada
Wagner RJ, Boulger RWJ, Oblinger CJ, Smith BA (2006) Guidelines and standard procedures for continuous water-quality monitors: station operation, record computation, and data reporting. U.S. Geological Survey Techniques and Methods 1-D3, http://pubs.usgs.gov/tm/ 2006/tm1d3/pdf/TM1D3.pdf

> Wang ZA, Cai WJ (2004) Carbon dioxide degassing and inorganic carbon export from a marsh-dominated estuary (the Duplin River): a marsh $\mathrm{CO}_{2}$ pump. Limnol Oceanogr 49:341-354

Wootton JT, Pfister CA, Forester JD (2008) Dynamic patterns and ecological impacts of declining ocean $\mathrm{pH}$ in a highresolution multi-year dataset. Proc Natl Acad Sci USA 105:18848-18853

Submitted: November 22, 2013; Accepted: March 19, 2014

Proofs received from author(s): April 28, 2014 